\title{
The Effects of Alternative Forced-Molting Methods on The Performance and Egg Quality of Commercial Layers*
}

- Author(s)
Molino $A B^{1 * *}$
Garcia $E A^{2}$
Berto $D A^{1}$
Pelícia $K^{3}$
Silva $A P^{1}$
Vercese $F^{1}$
1 Students of the Post-Graduation Program
in Animal Science - Departamento de
Produção Animal - FMVZ/Unesp-Botucatu.
2 Associate Professor of the Department of
Animal Production- FMVZ/Unesp-Botucatu.
3 Professor of the Department of Animal
Science, Unifenas- Alfenas.

Mail Address

Andréa de Britto Molino

Departamento de Produção Animal

FMVZ/Unesp

18.618-000. Botucatu, SP, Brasil.

E-mail: molinoab@fmvz.unesp.br

\section{Keywords}

Eggshell thickness, feed restriction, limestone, welfare.

\section{Acknowlegements}

The authors thank FAPESP for the M. Sc. grant and for funding this study.

\footnotetext{
* Project funded by Fundação de Amparo à Pesquisa do Estado de São Paulo- FAPESP.

** Grantee of Fundação de Amparo à Pesquisa do Estado de São Paulo- FAPESP.
}

\section{ABSTRACT}

This study aimed at studying alternative methods to induce molting and to compare them with the conventional forced-molting method (fasting). In the experiment, 420 70-week-old layers were used. The total experimental period was 140 days. Molting was induced during the first 28 days, when birds were submitted to the experimental treatments, and bird performance and egg quality parameters were determined during 112 subsequent days. A completely randomized experimental design was applied in a $5 \times 2$ factorial arrangement of five feed restriction regimes $(0,15,30,45$, or $60 \mathrm{~g}$ feed/bird/day) and with or without the addition of coarse-particle limestone to the feed, with seven replicates of six birds each. Egg quality was evaluated at the end of each 28-day period for three consecutive days, using three eggs per experimental unit (21 eggs/treatment), with a total of 210 eggs. It was concluded that feeding $15 \mathrm{~g}$ feed/bird/day to induce molting is feasible, as birds submitted to this treatment presented similar performance and better egg quality than those submitted to fasting during molting. The use of coarse-particle limestone during molting did not influence postmolting bird performance or egg quality.

\section{INTRODUCTION}

Forced molting has been widely used in commercial layer management with the aim of extending their productive life, thereby decreasing flock replacement costs. Fasting is the most frequently used method to induce molting due to its low cost and high efficiency (Rodrigues et al., 1995).

Due to the incompatibility between fasting and bird welfare, several methods to induce molting have been studied in the last decades. There is an increasing concern in researching alternatives that minimize bird stress and, at the same time, provide similar economic and egg-quality results as those obtained with the conventional fasting method. In the US and in the European Union, forced-molting methods based on fasting are condemned, and may soon become a restriction to egg imports by several countries (Garcia, 2004).

Many studies were carried out comparing fasting to other dietary methods. Garcia et al. (1996) worked with four periods of feeding a low-density diet during the resting period, but did not find any significant performance or egg-quality differences in 70- to 98-week-old layers.

Andreotti et al. (2005) investigated the use of qualitative feed restriction to induce molting, comparing feed fasting to nutrient restriction obtained by diluting a standard layer feed with $50 \%$ or $75 \%$ rice husks. The authors observed body weight loss of $25 \%$ after 20 and 10 days for diets diluted at 50 and $75 \%$, respectively, and concluded that feed dilution up to $50 \%$ can be used to induce molting without 
Molino AB, Garcia EA, Berto DA, Pelícia K, Silva AP, Vercese F
The Effects of Alternative Forced-Molting Methods on The Performance and Egg Quality of Commercial Layers causing severe stress, and therefore, providing better welfare.

Mineral nutrient restriction has been long used to induce molting. For instance, Ross and Herrick (1981) evaluated the effect of molting diets containing low salt as compared to fasting, and observed lower egg weight after molting in layers fed the low-salt diet.

The use of alternative methods to prolonged fasting to induce molting was also investigated by Scherer (2007). The restriction of calcium and phosphorus; calcium, phosphorus, and sodium; or calcium, phosphorus, sodium, and amino acids was compared to feeding ground corn for 28 days and to fasting for 14 days followed by a production feed up to 28 days. During the subsequent production cycle, the treatment with $\mathrm{Ca}$ and $\mathrm{P}$ restriction resulted in lower egg production and egg mass as compared to the remaining treatments. Feeding ground corn resulted in the worst Haugh unit, whereas the other treatments were not different in terms of eggshell quality or internal egg quality.

On the other hand, Onbasilar and Erol (2007) used high zinc level (10.000 ppm) for 10 days, barley whole grains for 10 days, or fasting for 10 days followed by ground corn for 28 days during molting, and found that fasting promoted the highest laying percentage after molting, followed by barley whole grains, and high zinc level.

Considering these findings, the aim of the present study was to evaluate forced-molting methods in commercial layer and their effects on egg production and quality.

\section{MATERIAL AND METHODS}

The experiment was carried out at the School of Veterinary Medicine and Animal Science of Unesp, Botucatu, SP, Brazil. A total number of 420 70-weekold Shaver layers were submitted to different experimental treatments to induce molting.

Birds were housed in a layer house containing 84 metal cages ( $1.00 \mathrm{~m}$ long $\times 0.45 \mathrm{~m}$ deep $\times 0.40 \mathrm{~m}$ high) placed in two double rows with a central aisle. Cages were equipped with trough feeders (one per cage) placed in front of the cages, and cup drinkers.

The total experimental period was of 140 days. Forced molting was performed during the first 28 days, when birds were submitted to the experimental treatments. It must be noted that the birds in the treatments that reached $25 \%$ body weight loss before 28 days were fed ad libitum immediately after that weight loss was obtained. The 112 subsequent days were divided in four periods of 28 days, when performance and egg quality parameters were determined.

A completely randomized experimental design was applied in a 5x2 factorial arrangement of five feed restriction regimes $(0,15,30,45$ or $60 \mathrm{~g}$ feed/bird/day) and with or without the addition of coarse-particle limestone, with seven replicates of six birds each, totaling 420 birds.

The following treatments were applied: T1production feed restricted to $60 \mathrm{~g} / \mathrm{bird} / \mathrm{day}$, and coarseparticle limestone supplied ad libitum; T2- production feed restricted to $60 \mathrm{~g} / \mathrm{bird} / \mathrm{day}$; T3- Production feed restricted to $45 \mathrm{~g} / \mathrm{bird} / \mathrm{day}$, and coarse-particle limestone supplied ad libitum; T4- Production feed restricted to $45 \mathrm{~g} / \mathrm{bird} / \mathrm{day}$; T5-Production feed restricted to $30 \mathrm{~g} / \mathrm{bird} / \mathrm{day}$, and coarse-particle limestone supplied ad libitum; T6- Production feed restricted to 30g/bird/day; T7- Production feed restricted to $15 \mathrm{~g} / \mathrm{bird} /$ day, and coarse-particle limestone supplied ad libitum; T8- Production feed restricted to 15g/bird/day; T9- feed fasting, and coarse-particle limestone supplied ad libitum; and T10- feed fasting.

The experimental feed was based on corn and soybean meal basis, and formulated according to the recommendations of Rostagno et al. (2005). Water was supplied ad libitum during the entire experimental period, and birds were submitted to a natural photoperiod of 12 hours of light during the forced molting period of 28 days, after which it was increased 30 min per week until reaching 17 hours of light per day. Egg production was daily recorded, whereas feed intake was recorded weekly. Egg quality was evaluated at the end of each 28-day period for three consecutive days, using three eggs per experimental unit (21 eggs/ treatment), with a total of 210 eggs.

The following parameters were evaluated after molting: laying percentage, feed intake, egg weight, egg mass, feed conversion ratio per dozen and per egg mass, mortality, and egg quality (specific gravity, eggshell breaking strength, eggshell thickness, percentages of eggshell, yolk, and albumen, and eggshell weight per surface area).

Data were submitted to analysis of variance, using the procedures of the General Linear Model of SAS ${ }^{\circledR}$ (SAS Institute, 2000). Means were compared by the test of Tukey $(p<0.05)$.

\section{RESULTS AND DISCUSSION}

Table 1 show the performance results of the layers submitted to the experimental treatments. 
Molino AB, Garcia EA, Berto DA, Pelícia K, Silva AP, Vercese F
The Effects of Alternative Forced-Molting Methods on The Performance and Egg Quality of Commercial Layers

\begin{tabular}{|c|c|c|c|c|c|c|c|}
\hline Feed restriction & $\begin{array}{l}\mathrm{Fl}^{1} \\
(\mathrm{~g})\end{array}$ & $\begin{array}{l}\text { Lay }^{2} \\
(\%)\end{array}$ & $\mathrm{FCR} / \mathrm{dz}^{3}$ & $\mathrm{FCR} / \mathbf{k g}^{4}$ & $\begin{array}{c}\text { Egg } W^{5} \\
(g)\end{array}$ & $\underset{(g)}{\operatorname{Egg~} M^{6}}$ & $\begin{array}{r}\text { Mort }^{7} \\
(\%)\end{array}$ \\
\hline $0 \mathrm{~g}$ & 111.8 & $75.4 \mathrm{~A}$ & $1.79 \mathrm{~B}$ & $2.27 \mathrm{~B}$ & $65.8 \mathrm{~A}$ & $49.6 \mathrm{~A}$ & 0.20 \\
\hline $15 \mathrm{~g}$ & 110.4 & $74.8 \mathrm{~A}$ & $1.78 \mathrm{~B}$ & $2.26 \mathrm{~B}$ & $65.8 \mathrm{~A}$ & $49.1 \mathrm{~A}$ & 0.34 \\
\hline $30 \mathrm{~g}$ & 108.2 & $64.0 \mathrm{~B}$ & $2.07 \mathrm{~A}$ & $2.75 \mathrm{~A}$ & $63.0 \mathrm{~B}$ & $40.4 \mathrm{~B}$ & 0.40 \\
\hline $45 \mathrm{~g}$ & 109.2 & $63.7 \mathrm{~B}$ & $2.07 \mathrm{~A}$ & $2.79 \mathrm{~A}$ & $62.0 \mathrm{~B}$ & $39.5 \mathrm{~B}$ & 0.30 \\
\hline $60 \mathrm{~g}$ & 108.6 & $62.9 \mathrm{~B}$ & $2.10 \mathrm{~A}$ & $2.72 \mathrm{~A}$ & $64.4 \mathrm{AB}$ & $40.5 \mathrm{~B}$ & 0.40 \\
\hline \multicolumn{8}{|l|}{ Limestone } \\
\hline w/ & 109.6 & 67.7 & 1.98 & 2.59 & 64.1 & 43.5 & 0.41 \\
\hline$w / 0$ & 109.7 & 68.6 & 1.95 & 2.53 & 64.3 & 44.1 & 0.24 \\
\hline Mean & 109.6 & 68.1 & 1.97 & 2.56 & 64.2 & 43.8 & 0.33 \\
\hline \multicolumn{8}{|l|}{ Probability } \\
\hline Restriction & $>0.05$ & $<0.01$ & $<0.01$ & $<0.01$ & $<0.01$ & $<0.01$ & $>0.05$ \\
\hline Limestone & $>0.05$ & $>0.05$ & $>0.05$ & $>0.05$ & $>0.05$ & $>0.05$ & $>0.05$ \\
\hline Rest $x$ limes & $>0.05$ & $>0.05$ & $>0.05$ & $>0.05$ & $>0.05$ & $>0.05$ & $>0.05$ \\
\hline
\end{tabular}

Means followed by different letters in the same column are significantly different by the test of Tukey ( $p<0.05)$. 1 - Feed intake, 2 - Lay, 3 - Feed conversion ratio per dozen eggs, 4 - Feef conversion ratio per egg mass, 5 - Egg weight, 6 - Egg mass, 7- Mortality.

No interaction between feed restriction and the addition of coarse-particle limestone to the diet was detected. Moreover, there were no significant effects of limestone on any of the evaluated parameters.

Feed restriction had no influence on feed intake or mortality. These results are opposed to the findings of Rolon et al. (1993), who observed higher feed intake in layers submitted to conventional forced molting as compared to those fed a low-energy diet ad libitum, low-energy diet limited to $45 \mathrm{~g} / \mathrm{bird} / \mathrm{day}$, and lowenergy diet limited to $45 \mathrm{~g} / \mathrm{bird}$ on alternate days up to 21 days, followed by ad libitum feeding up to 28 days.

There were significant effects of feed restriction on laying percentage, feed conversion ratio per dozen eggs and per egg mass, egg weight, and egg mass. The birds submitted to the treatments with lower feed supply presented better performance results after molting; however, the performance of birds fed $15 \mathrm{~g}$ feed/bird/day was statistically similar to the birds submitted to fasting.

These results are consistent with those of Biggs et al. (2003), who found similar egg production and feed conversion ratio per dozen eggs and per egg mass between layer fed supplemented wheat during molting and those fasted for 10 days during a conventional forced-molting process. On the other hand, Vermaut et al. (1998), working with broiler breeders submitted to molting by one-day fasting followed by one of three feeds: molting feed supplemented with $12 \%$ defatted jojoba bran fed ad libitum, molting feed restricted to $43.6 \mathrm{~g} / \mathrm{bird} /$ day org round wheat (five days at $20 \mathrm{~g} /$ bird/day, followed by increasing supply of $30,40,50$, and $60 \mathrm{~g} / \mathrm{bird} /$ day during the four remaining weeks), observed lower egg production in birds restricted-fed at 43.6g/bird/day. Similarly, Ramos et al. (1999), when researching the use of a low-density diet restricted to $45 \mathrm{~g} / \mathrm{bird} /$ day for 27 days to induce molting as compared to the conventional method, found worse laying percentage and feed conversion ratio during the second production cycle in birds fed the low-density diet.

Eggs from layers submitted to higher feed restriction (fasting and $15 \mathrm{~g} / \mathrm{bird} /$ day) were heavier, similarly to the findings of Oliveira et al. (1994), who observed that layers submitted to fasting during molting laid heavier eggs as compared to those fed a low-energy diet ad libitum or restricted fed at $45 \mathrm{~g} / \mathrm{bird} /$ day for 27 days.

Table 2 presents the egg quality results of the experimental treatments post-molting.

Feed restriction significantly interacted with dietary coarse-particle limestone only as to eggshell breaking strength.

Limestone significantly affected yolk percentage, with birds fed coarse-particle limestone during the molting period presenting higher yolk percentage after molting.

There were no effects of feed restriction on egg specific gravity. This is consistent with the results of Rolon et al. (1993), who studied five forced-molting methods, as described above, and did not observed any significant effects of treatments on egg specific gravity.

Eggshell breaking strength, eggshell thickness, percentages of yolk, eggshell, and albumen, as well as eggshell weight per surface area were significantly influenced by the different levels of feed restriction applied. Layers submitted to conventional molting (fasting) presented the worst egg quality results, except for albumen percentage, which was expected, as albumen percentage is inversely proportional to yolk percentage. 


\section{Molino AB, Garcia EA, Berto DA, Pelícia K, Silva AP, Vercese F}

The Effects of Alternative Forced-Molting Methods on The Performance and Egg Quality of Commercial Layers

\begin{tabular}{|c|c|c|c|c|c|c|c|}
\hline Feed restriction & SG $^{1}$ & $\begin{array}{l}\mathrm{BS}^{2} \\
(\mathrm{~g})\end{array}$ & $\begin{array}{l}\text { Thick }^{3} \\
(\mathrm{~mm})\end{array}$ & $\begin{array}{c}\text { Yolk }^{4} \\
(\%)\end{array}$ & $\begin{array}{c}\text { Shell }^{5} \\
(\%)\end{array}$ & $\begin{array}{l}\text { Alb }^{6} \\
(\%)\end{array}$ & $\begin{array}{c}\mathrm{EWSA}^{7} \\
\left(\mathrm{mg} / \mathrm{cm}^{2}\right)\end{array}$ \\
\hline $0 \mathrm{~g}$ & 1.085 & $2.601 \mathrm{~B}$ & $0.37 \mathrm{~B}$ & 24.87 B & $8.97 \mathrm{~B}$ & $66.21 \mathrm{~A}$ & 77.79 B \\
\hline $15 \mathrm{~g}$ & 1.087 & $2.771 \mathrm{~A}$ & $0.38 \mathrm{~A}$ & $26.26 \mathrm{~A}$ & $9.36 \mathrm{~A}$ & $64.38 \mathrm{~B}$ & $80.61 \mathrm{~A}$ \\
\hline $30 \mathrm{~g}$ & 1.088 & $2.753 \mathrm{~B}$ & $0.38 \mathrm{~A}$ & $25.91 \mathrm{~A}$ & $9.38 \mathrm{~A}$ & $64.70 \mathrm{~B}$ & $80.58 \mathrm{~A}$ \\
\hline $45 \mathrm{~g}$ & 1.087 & $2.815 \mathrm{~A}$ & $0.38 \mathrm{~A}$ & $25.96 \mathrm{~A}$ & $9.26 \mathrm{AB}$ & $64.78 \mathrm{~B}$ & $79.91 A B$ \\
\hline $60 \mathrm{~g}$ & 1.093 & $2.801 \mathrm{~A}$ & $0.38 \mathrm{~A}$ & $26.18 \mathrm{~A}$ & $9.37 \mathrm{~A}$ & $64.45 \mathrm{~B}$ & $80.61 \mathrm{~A}$ \\
\hline \multicolumn{8}{|l|}{ Limestone } \\
\hline w/ & 1.087 & 2776 & 0.37 & $25.66 \mathrm{~B}$ & 9.27 & 65.07 & 79.99 \\
\hline w/o & 1.089 & 2720 & 0.37 & $26.00 \mathrm{~A}$ & 9.27 & 64.73 & 79.80 \\
\hline Mean & 1.088 & 2748 & 0.37 & 25.83 & 9.27 & 64.90 & 79.89 \\
\hline \multicolumn{8}{|l|}{ Probability } \\
\hline Restriction & $>0.05$ & $<0.01$ & $<0.01$ & $<0.01$ & $<0.01$ & $<0.01$ & $<0.01$ \\
\hline Limestone & $>0.05$ & $>0.05$ & $>0.05$ & $<0.05$ & $>0.05$ & $>0.05$ & $>0.05$ \\
\hline Rest $\mathrm{x}$ limes & $>0.05$ & $<0.05$ & $>0.05$ & $>0.05$ & $>0.05$ & $>0.05$ & $>0.05$ \\
\hline
\end{tabular}

Means followed by different letters in the same column are significantly different by the test of Tukey $(p<0.05) .1$ - Specific gravity, 2 - Eggshell breaking strength, 3 - Eggshell thickness, 4 - Yolk percentage, 5 - Eggshell percentage, 6 - Albumen percentage, 7 - Eggshell weight per surface area.

Table 3 - Details of the interaction between feed restriction and coarse-particle limestone for eggshell breaking strength.

\begin{tabular}{|c|c|c|c|c|c|c|}
\hline \multirow[t]{2}{*}{ Limestone } & \multicolumn{5}{|c|}{ Feed restriction } & \multirow[b]{2}{*}{ Mean } \\
\hline & $0 \mathrm{~g}$ & $15 g$ & $30 \mathrm{~g}$ & $45 g$ & $60 \mathrm{~g}$ & \\
\hline w/ & $2575 \mathrm{~b}$ & $2773 a b$ & $2749 a b$ & $2835 a$ & 2949Aa & 2776 \\
\hline w/o & 2627 & 2769 & 2757 & 2795 & $2654 B$ & 2720 \\
\hline Mean & 2601 & 2771 & 2753 & 2815 & 2801 & 2748 \\
\hline
\end{tabular}

Means followed by different capital letters in the same column and by different small letters in the same row are significantly different by the test of Tukey $(p<0.05)$.

Table 3 shows the details of the interaction found in Table 2.

The egg quality results obtained in the present study are consistent with those observed by Garcia et al. (1996) and Scherer et al. (2007), who did not find any effects of treatments to induce molting on post-molting egg quality, as the egg is produced during a very short period of time, and therefore depends on the availability of nutrients at the time it is formed, independently of the molting period.

In birds that were not fed limestone, eggshell breaking strength worsened as feed restriction increased. As to layers fed $60 \mathrm{~g}$ feed/day, those that did not receive limestone presented better eggshell breaking strength. The results of limestone utilization during the molting period seem to be adequate when considering egg use during molting (BuxadéCarbó, 1987). However, these results may be controversial as to the use of limestone during molting and post-molting egg quality is analyzed. Scherer et al. (2007) did not observe any effect of calcium and phosphorus restriction during molting on post-molting egg quality, which is consistent with the findings of the present study.

\section{CONCLUSIONS}

It was concluded that feeding $15 \mathrm{~g}$ feed/bird/day to induce molting is feasible, as birds submitted to this treatment presented similar performance and better egg quality than those submitted to fasting during molting. The use of coarse-particle limestone during molting did not influence post-molting bird performance or egg quality.

\section{REFERENCES}

Andreotti MO, Souza KM, Suzuki FM, Ribeiro SS, Allaman IB, Ferreira JZ. Efeito de diferentes métodos de muda forçada na redução de peso corporal de poedeiras comerciais. Anais do $3^{\circ}$ Congresso de Produção, Comercialização e Consumo de Ovos; 2005; São Paulo, SP. Brasil. p.76.

Biggs PE. et al. Evaluation of nonfeed removal methods for molting programs. Poultry Science 2003; 82(5):749-753.

Buxadécarbó C. La gallina ponedora: sistema de explotación y técnicas de producción. Castelo: Mundi prensa; 1987. 377 p.

Garcia EA, Mendes AA, Pinto MCL, Garcia SCR. Avaliação dos parâmetros físicos de poedeiras semi-pesadas submetidas à muda forçada. Veterinária e Zootecnia 1996; 8:65-73. 
Garcia EA. Muda forçada em poedeiras comerciais e codornas. Anais da Conferência APINCO de Ciência e Tecnologia Avícolas; 2004; Santos, São Paulo. Brasil: FACTA; 2004. p. 45-62.

Onbasilar EE, Erol $\mathrm{H}$. Effects of different forced molting methods on postmolt production, corticosterone level, and immune response to sheep red blood cells in laying hens. Journal Applied Poultry Reserch 2007; 16:529-536.

Oliveira RM. Avaliação comparativa de alguns métodos de indução de muda em poedeiras comerciais [dissertação]. Lavras(MG): Escola Superior de Agricultura de Lavras; 1994.

Rodrigues PB, Bertechinii AG, Oliveira BL. et al. Fatores nutricionais que influenciam o desempenho e a qualidade do ovo de poedeiras comerciais no segundo ciclo de produção. I - Níveis de AAST e metionina. Anais da $32^{a}$ Reunião da Sociedade Brasileira de Zootecnia; 1992; Brasília, DF. Brasil; 1995. p.478-479.

Ramos RB, Fuentes MFF, Espindola GB, Lima FAM, Freitas ER. Efeitos de diferentes métodos de muda forçada sobre o desempenho de poedeiras comerciais. Revista Brasileira de Zootecnia 1999; 28(6): 1340-46.

Rolon A, Buhr RJ, Cunningham DL. Twenty four hour feed withdrawal and limited feeding as alternative methods for induction of molt in laying hens. Poultry Science 1993; 72:776-785.

Ross E, Herrick RB. Forced rest induced by molt or low-salt diet and subsequent hen performance. Poultry Science 1981; 60(1):63-67.

Rostagno HS, Albino LFT, Donzele JL, Gomes PC, Oliveira RF, Lopes DC, Ferreira AS, Barreto SLT. Tabelas brasileiras para aves e suínos: composição de alimentos e exigências nutricionais. 2ed. Viçosa (MG): UFV; 2005

Scherer MR. Métodos alternativos de muda forçada para poedeiras comerciais. Botucatu [mestrado]. Botucatu (SP): Faculdade de Medicina Veterinária e Zootecnia, Universidade Estadual Paulista; 2007.

Statistical Analysis System. User's guide: statistics. Cary; 2000.

Vermaut S, Coninck KDE, Onagbesan O. A jojoba-rich diet as a new forced molting method in poultry. Journal of Applied Poultry Research 1998; 7:239-246. 